\title{
ANGLO-AMERICAN AND CONTINENTAL TRADITIONS IN ADVOCACY BEFORE INTERNATIONAL COURTS AND TRIBUNALS
}

\author{
James Crawford ${ }^{*}$ \\ Alain Pellet ${ }^{\dagger}$ \\ Catherine Redgwell
}

\section{Keywords}

Advocacy, Tradition, International Courts and Tribunals

\begin{abstract}
The Keynote Debate 'Anglo-American and Continental Traditions in Advocacy before International Courts and Tribunals' took place on 19 May 2013 in the Divinity School of St John's College, Cambridge, as part of the Second Annual CJICL Conference. The debate pitted Professor James Crawford against Professor Alain Pellet and was moderated by Professor Catherine Redgwell. It was made possible with the generous support of Freshfields Bruckhaus Deringer. The CJICL expresses its gratitude to Professors Crawford, Pellet and Redgwell for their kind permission to print this transcript; and to Naomi Burke, Godsglory Ifezue, Christopher Sargeant, Estelle Wolfers and Lawrence Li for their help with the transcription.
\end{abstract}

Professor Catherine Redgwell (CR): It is a really great pleasure to be here and to moderate this keynote debate on Anglo-American-perhaps I should say Anglo-Australian-and continental traditions in advocacy before international courts and tribunals. I know that our very distinguished debaters need no introduction, but there may be a few things that you may be unaware of. What you do know, of course, is that Professor Alain Pellet is Professor of Public International Law at the Université Paris-Ouest Nanterre La Défense and is currently the President of the French Society of International Law. You are also aware that he attained the age of majority, that is 21 years, in the International Law Commission (ILC)...

\footnotetext{
* Whewell Professor of International Law and Fellow of Jesus College, University of Cambridge.

† Professor of Public International Law, Université Paris-Ouest Nanterre La Défense.

‡ Chichele Professor of International Law and Fellow of All Souls College, University of Oxford.
}

Copyright $\odot$ the Author(s).

This work is licensed under a Creative Commons Attribution-NonCommercial-NoDerivs 3.0 License. 


\section{Professor Alain Pellet (AP): 22}

CR: Ok, well, I am sure that is the age of majority somewhere...[laughter]. In the ILC he tackled one of my favourite subjects: reservations to treaties. He has been counsel in over 60 cases before the ICJ and arbitral tribunals. On my right is Professor James Crawford, who is of course the Whewell Professor of International Law here at Cambridge. He also served-and they were contemporaneous for a large spell-on the ILC, where he tackled such lightweight subjects as the International Criminal Court and state responsibility. $\mathrm{He}$ also has extensive advocacy experience, with 50 cases before the ICJ and other international tribunals and over 20 arbitrations.

What you might not be so aware of is that they have appeared-as they are now-on opposite sides in over a dozen cases, and that they have appeared together in others. They have also written, of course, on advocacy before international courts and tribunals, and together they wrote the following about advocacy before such courts and tribunals. ${ }^{1}$ They refer to it as an 'aventure sociale; it obliges persons formed by very different methods of thinking and modes of legal reasoning to form an 'intellectual coexistence'. Among other things, the diversity of approaches is reflected in modes and styles of pleadings. It is this that will be our first topic for debate: the style of oral proceedings. I turn to the stylish Professor Pellet to kick us off.

AP: Thank you very much. I will be a bit longer than for the next topic as I want to make some preliminary points. First, usually I am extremely rude-I hope I will be so today as well [laughter] - but exceptionally I want to do something polite and thank the organisers, which I really do because I think you succeeded amazingly in having this conference.

My second preliminary point is that, during this debate, I will speak only for myself. I have not really exchanged views with James on what we are going to say; we have just tried to agree on the different topics and I suppose that the two of us will mainly base ourselves on our rather heavy experience as advocates before the World Court, primarily, and accessorily before international arbitral tribunals, including ICSID. Therefore, I think we will present, unavoidably, an impressionistic rather than a scientific view. I am not sure that it can be dealt with scientifically, but certainly I will not try to do so. So you will hear about the Anglo-American tradition as perceived by Alain Pellet, and

\footnotetext{
1 J Crawford \& A Pellet, 'Anglo-Saxon and Continental Approaches to Pleading before the ICJ', in I Buffard, J Crawford, A Pellet \& S Wittich (eds), International Law Between Universalism and Fragmentation: Festschrift in Honour of Gerhard Hafner (2009) 831-867.
} 
the continental tradition as viewed through James Crawford's lens, which is unavoidably subjective.

When I speak of the Anglo-American tradition, I speak of persons, rather than an abstract concept. For me, advocacy in the Anglo-Saxon or Anglo-American tradition would be personified by Sir Ian Brownlie, Sir Arthur Watts, Dame Rosalyn Higgins, Rodman Bundy, Sir Michael Wood, Professor Vaughan Lowe and Professor Alan Boyle. They are persons and when you speak of styles, clearly they have very different styles. My perception of advocacy before the ICJ is wider than my practice in the arbitration field. I am probably part of what they call the invisible (or too visible?) bar of the ICJ. The late Sir Ian Brownlie would have said 'the Mafia of the ICJ', so both of us are Mafiosi [laughter] - and this leads me to my second general remark concerning the whole topic.

When you know how different these colleagues-and néanmoins amis as we say in French-I have just mentioned are, you can certainly wonder whether there can be such a thing as an Anglo-American tradition of advocacy before the ICJ and even less so before other international tribunals. Yet, I have the feeling that the Anglo-American-in French we usually say 'Anglo-Saxon', which has the great advantage of including Australians who are not Anglo-American as far as I know-that the Anglo-Saxon touch in advocacy does exist and can be contrasted with the continental approach. I have participated in something like 60 or 70 legal teams, both in contentious and non-contentious cases, and I have always been struck by the fact that, as a Frenchman, I have never, or nearly never, had any problem in understanding - to understand a point of view does not mean to share it! - the views of my German, Italian or Spanish colleagues-not to speak of the Belgians. We can understand one another. By contrast, I have quite often the impression that my Anglo-Saxon colleagues and I have problems in understanding one another and that the opposition between Anglo-Saxon empiricism and Latin Cartesianism is not that much of a caricature. It does, I think, correspond to a deep cultural difference, which goes beyond legal advocacy or legal culture but is rooted in our respective educational background and in culture tout court, not only legal culture. I must say that-although I hate looking too nice to my old accomplice-James Crawford is no doubt an Anglo-Saxon, but he has an extraordinary quality-not shared by all his colleagues-in that he genuinely listens and always tries to understand the other's point of view. Even more, quite often he succeeds in understanding! [laughter] With several of his colleagues I have the impression that I can explain again and again what I have in mind; it usually does not work.

With this regrettably indulgent parenthesis closed, I must admit that the 
worst are usually not the Australians, nor the Americans or the Canadians, but the British. Each of my British colleagues-including the Scots for that matter-is an island, with sometimes for me a totally disconcerting way of thinking [laughter]. This said, I must say that this diversity is certainly one of the most fascinating and enjoyable parts of being an international advocate, if that means something. This confrontation of points of view is extremely intellectually enriching. It is also a necessity: before the large world tribunals-when you speak before the ICJ with 15 or 17 judges, or when you speak before the ITLOS you have 21 or 23 judges - the judges all come from different parts of the world. Even if they virtually all speak English, at least half of them think 'continental'. They do not think English, they do not think common law. When a team is correctly constituted, it has to have a good balance between the various legal cultures of its members-keeping in mind that when you speak of legal cultures, I think it is wrong to say that there are more than two. With the greatest respect for the Islamic or the Chinese cultures, international law is made up of two legal cultures, not of hundreds. I think that what is important is to have a real balance between those two. As very aptly written by the much missed Keith Highet: 'counsel must always remember that it is an International Court that we are addressing, and that this International Court does indeed function internationally-not in one, but in two official languages.' I think the important thing is not so much that it functions in two official languages, but that the law it has to apply is based on two legal cultures. Well, these were long preliminary remarks; I will shortly address advocacy style.

Indeed, pleading styles before the ICJ, to take again the example I know best, are extremely different. I would think that this comes more from personal inclination than from legal culture, as far as the styles are concerned. Indeed, although Ian Brownlie was my mentor in my first case, in Nicaragua $v$ United States of America, I have never imitated his pleading style, which I found terribly boring [laughter]. But I suppose that Michel Virally, who was a French leading counsel in the 60's or 70's, was this kind of advocate; while in spite of his seemingly gruff attitude, James Crawford is infinitely more lively. That said, and again with probably James as a most notable exception-I think the organisers made a very bad choice in asking James to be the representative of Anglo-American culture-with his exception-maybe joined by Philippe Sands in some kind, and

\footnotetext{
${ }^{2}$ K Highet, 'Problems in the Preparation of a Case', in C Peck \& R S Lee (eds.), Increasing the Effectiveness of the International Court of Justice. Proceedings of the ICJ/UNITAR Colloquium to celebrate the $50^{\text {th }}$ anniversary of the Court (1997) 145.
} 
in the past by Rosalyn Higgins - there is at least a dominant trait amongst British advocates: they try to be impassive. Impassivity is not always equivalent to boringness or a soporific tone, but it happens. Yet as was shown by Sir Derek Bowett, Sir Eli Lauterpacht or recently by Sir Frank Berman, you can be impassive while being quite enthralling. These British colleagues have understood that respect to the Court does not mean being as boring as you can [laughter]. Sam Wordsworth, for example, is the paragon of this incredibly British inimitable tone, which combines firmness and forensic stillness with apparent modesty and an air of untouchability. This is very British. Sir Arthur Watts also had this fascinating behaviour. Yet, whereas equanimity seems a dominant trait amongst British counsel, this is certainly less true for their American colleagues. Just to take two usual suspects, Rodman Bundy and Paul Reichler are extremely expressive and lively in their pleadings before the ICJ. Before ICSID tribunals, I have seen people like John Veeder be quite intense pleaders as well.

Now if you turn to the Latin side, the picture is completely different. I suggest that Latin pleadings are characterised by two aspects. First, we usually are more lively and passionate; either for what I would call a colourful note-like Luigi Condorelli, who is a very passionate pleader-or a more dramatic or even tragic register-like Marcelo Kohen [laughter]. The second trait is that our continental style is also more flowery, with more dramatic gesture and effets de manche. Personally I try to avoid this, although I confess that I cannot always help it [laughter]. Then there is the problem with our literacy. Again, all of this is a cliché-and there are of course exceptions-but Latin lawyers, especially the French, have a tendency to refer to their literary heritage. Indeed, contemporary references are most often recognised. But when you venture-as I did recently at ITLOS-to recite some of Corneille's stanzas, I am afraid it flops. ${ }^{3}$ Whether we-the French, the Latins-like it or not, the universal culture is Anglo-Saxon, or Anglo-American; I am afraid more American than English, although Alice in Wonderland is probably the most quoted book before the World Court [laughter]. I confess en passant that I am quite wary of the frequent references by our Anglo-Saxon colleagues to the white rabbit or Cheshire cat; this is English, not French! I think it is too much [laughter]. As has been aptly noted, humour is often culture specific and can even be offensive.

Now, very quickly, jokes... Jokes are a very important part of pleadings before the Court. Can you afford joking before the World Court? This is a fascinating

3 Dispute concerning delimitation of the maritime boundary between Bangladesh and Myanmar in the Bay of Bengal (Bangladesh/Myanmar), ITLOS, ITLOS/PV.11/15/Rev.1, 24 September 2011 (morning), 19. 
topic that probably warrants a doctoral thesis [laughter]. I will only give you my short answer: yes you can, but with some restraint. Second, I think that the English sense of humour is quite different from the continental sense of humour. Our English counterparts will usually say that humour is misplaced before the court. Quite recently Sir Michael Wood was pleading in a case before ITLOS. Our adversaries were exaggerating and repeatedly used quotes from English authors and even invoked Star Trek; I suppose only two of the 23 judges knew what it was about [laughter]. Then Sir Michael started his speech saying 'I can assure you that I will not be quoting any English poets; there will be no Shakespeare, no Poe, no Blake; there will not even be rabbit'-all of them having been quoted by our opponents. "There will be no Sherlock Holmes and there will certainly be no Star Trek $^{4}$ and then he went on and added a lot of purely British jokes [laughter]. And this is my last word in this section-I promise my other comments will be much shorter-usually our British colleagues' humour is a good representation of the English sense of humour and my distinguished Australian friend is no exception, in that he has a good sense of scratching without hurting. Thank you [applause].

CR: I will now give the floor to the gruff but lively Professor Crawford.

Professor James Crawford (JC): Well, I will start at the end, with the jokes. I once had a map speech starting with the lines 'some maps are born great, some achieve greatness, and some have greatness thrust upon them' [laughter]. ${ }^{5}$ Since the case was about a non-annexed map, unrelated to the treaty, the point of the joke-and Shakespeare is universal-was immediately caught by the tribunal. But general jokes-'did you hear the one about the man who...'-do not work; the jokes must be relevant to the case. In the Kosovo case, I declared the independence of South Australia. ${ }^{6}$ Later on the spouse of one of the judges asked me if she could be president of South Australia [laughter]. This was a sure sign that they were still thinking about the declaration of independence, which of course was not unlawful but was completely ineffective. The Court was not asked in the Kosovo case whether the declaration was ineffective, but whether it was unlawful. You do not tell jokes in the Court, but you do want to keep them awake [laughter]. The late Tom Franck and I had a competition to see who could make most of the bench laugh, or at least smile. His team won, quite unfairly, with a reference to

\footnotetext{
${ }^{4}$ Ibid., ITLOS/PV.11/7/Rev.1, 15 September 2011 (afternoon), 17.

5 See Sovereignty over Pulau Ligitan and Pulau Sipadan (Indonesia/Malaysia), ICJ Verbatim Record, CR/2002/32, 7 June 2002 (afternoon), 22.

${ }^{6}$ See Accordance with International Law of the Unilateral Declaration of Independence by the Provisional Institutions of Self-Government of Kosovo, ICJ Verbatim Record, CR 2009/32, 10 December 2009 (morning), 47.
} 
someone's mobile phone going off in the audience. That makes Alain's point, that jokes are very culture specific and that you have to be very careful. That is enough on jokes, let us talk seriously.

Alain mentioned some of the characteristics of French advocates. When I think of French advocates, I think of Alain, because he is quite unusual in being totally dominant as an advocate on the francophone side. Of course I have heard other advocates and I worked with them-Pierre Dupuy, Jean-Pierre Cot, Marcelo Kohen, Luigi Condorelli, Pierre Klein and some of his Belgian colleagues-but Alain has probably done more cases than they have done all together. Why is that? Because he is, quite frankly, the best. It is a bit difficult to draw characteristics from the best of the bunch, but I will take the risk and do it: lively, yes; dramatic, yes; flowery, not normally; gestures, yes. His greatest gesture was probably with an egg-in Bangladesh/Myanmar.

AP: Ah, l'oeuf... [laughter]. That was a boiled egg, because it was in response to a point made by Alan Boyle [laughter]. ${ }^{7}$

JC: Good to know it was boiled; that reference was lost in translation [laughter]. Literary references: very rarely-from Alain I understand that is because of the worldly intransitivity of French culture [laughter]; he has to bear with Shakespeare, and Sherlock Holmes. But I once compared the agent of an opposing state to Winnie-the-Pooh, who wanted both condensed milk and honey on his bread; ${ }^{8}$ that reference was completely lost on the audience [laughter].

One thing that Alain did not mention was length, because French advocates go on and on and on [laughter]. Now it is true that it takes you $30 \%$ more words to say in French what you would otherwise have said in English; that is why French translators always complain about your speed. The English translators have to do less, the French ones more, so they are always telling you to slow down. In the East Timor case, the first case that Alain and I were in together, the crucial and only point that Australia could win on was the Monetary Gold principle-without it we would have lost. So we argued the point twice: once in English and once in French. Those days the bench was much more francophone. The anglophones could understand the English way of arguing and the francophones would understand the French way of arguing. So I argued the Monetary Gold

\footnotetext{
Bangladesh/Myanmar, above n 3, ITLOS/PV.11/8, 16 September 2011 (afternoon), 33. For the video recording, see <http://wm.rosebud-media.net/itlos/archive/20110919_itlos_en_007.asf> [accessed 15 August 2013].

8 Territorial and Maritime Dispute (Nicaragua v Colombia), ICJ Verbatim Record, CR 2012/11, 26 April 2012 (afternoon), 18.
} 
case for 45 minutes in a characteristically restrained way. ${ }^{9}$ Then Alain argued the Monetary Gold case for about two hours [laughter]. ${ }^{10}$ Even the Australian team was wilting by the end of it. But we won on the Monetary Gold case. And since then I have always thought repetition is a bad thing in pleading, but not when it is repetition of the same argument in French and English.

With regard to differences of style, the first point to make about francophone advocacy, which is brought to a high pitch by Alain and some of his colleagues, is that, I think, it is more difficult to be bad in French than it is in English. At least, most of the francophone advocates I have heard have been good or very good. They sound wonderful because they are speaking such a lovely language. But Alain is really head-and-shoulders above the rest. On the other hand, he is not characteristic of the French bar-if he even is a member of the French bar.

AP: No, no.

JC: He is not a member of the bar. He wears his academic robes; the francophones are very colourful and there is no problem wearing academic gowns. We have to wear black gowns and wigs-although as an Australian I do not wear a wig. The consequence of the colour comes out in the advocacy to some degree. I have also sat on a francophone tribunal at the OECD, with Jean Massot of the Conseil d'État as President. I did about 30 cases with him, employment cases mostly. We never disagreed on points of substance, except in one case. We always agreed independently on what the result would be. That made me very sceptical of the view that anglophone and francophone lawyers tend to think differently. They may think in different ways, but in the end they come to the same conclusion in relation to a given fact situation. The difference between us was that when he wrote the judgment, which he did most of the time, it was about a page-and-a-half-considerant etc-blowing the argument out of the water in three lines. When I wrote the judgment, which I did in a minority of cases, it was ten or fifteen pages, blowing the argument out of the water very slowly. These are public judgments and you can tell who has written them at a glance.

By contrast, in terms of advocacy French advocates take longer and they are in a way more thorough. They use more references than English advocates in general-Alain is particularly good at this because his mastery of the jurisprudence of the Court is unequalled-and they present it in a scholarly way. That is because they are scholars; there are almost no French advocates at the interna-

\footnotetext{
9 East Timor (Portugal v Australia), ICJ Verbatim Record, CR 95/7, 6 February 1995 (morning), 51-60.

${ }^{10}$ Ibid., 60-83 and CR 95/8, 7 February 1995 (morning), 8-33.
} 
tional level who are full-time members of the bar. That raises the question which does not really fit within this first theme but which I will raise: what is going to happen with the next generation of advocates? That is an important question and quite a difficult one to answer. There is a major competition on the anglophone side between the large law firms-one of them is our sponsor-and the international lawyers who are professors. I am not so sure that the professors will retain the dominant status that they have enjoyed in the past. Eli [Lauterpacht] was in his generation-if I may say that of a generation that is still going on-one of the great advocates. To give you an example: his speech in the resumed Nuclear Weapons case in 1995 on the science was a masterful piece of work, one of the best speeches that has even been delivered on science ${ }^{11}$ - a very difficult thing to do, because you know much more than the bench does about science and you got to convey it in a way that does not send them to sleep and makes them vote your way. Eli went to the bar before he became an academic lawyer and has always been both. He is very unusual in his generation in that respect. Now we have a new generation of people who are approaching international advocacy more from the side of the profession, or the professions I should say, as they belong to different sorts of bars. And whether the academics will be allowed to or will want to maintain their past dominance in advocacy is in question. It is very difficult trying to do both jobs and whether the university will allow us to do both jobs is another question [applause].

AP: Just one point: I want to join you in saying that the best pleading I have ever heard was Eli's in the Nuclear Test case-and unfortunately I was his opponent [laughter]. ${ }^{12}$

CR: Our debaters have very kindly consented to take questions after each point of debate-there are more to come-so it is over to you for any burning questions or comments.

Caroline Foster: When you appear before the international court representing a state, do you consider that what you say could be taken to represent state practice, and if not, why not?

Rafal Manko: I have a question whether on the civil law side, would you say that for example German lawyers as pleaders before the ICJ are different from the

${ }^{11}$ Request for an Examination of the Situation in Accordance with Paragraph 63 of the Court's Judgment of 20 December 1974 in the Nuclear Tests (New Zealand v France) Case, ICJ Verbatim Record, CR 1995/19, 11 September 1995 (afternoon), 48-67.

${ }^{12}$ See A Pellet's contribution to The Function of Law in the International Community: Tribute to Sir Elihu Lauterpacht, <http://www.law.cam.ac.uk/faculty-resources/summary/the-function-oflaw-in-the-international-community-tribute/6216> [accessed 15 August 2013]. 
French, or would you say that the civil law side of litigants is rather homogenous. You argued there were just two legal systems, but would you divide these further or rather not?

Marie Claire Cordonier Segger: Thank you for this excellent opening session in this debate. My question is, is there a point that you are actually in contention on at the moment? [laughter]

JC: Alain and I wrote a joint article in the Hafner Festschrift in which we represented the civil and common law sides, which you might like to read, and Alain was very upset because I kept agreeing with him [laughter]. ${ }^{13}$ My preference is to minimise the differences between the common law and the civil law in many respects and Alain's is to maximise them. As for state practice, yes, definitely, because what you say in the International Court is read by the agent and approved by the agent, and it is as such a representative view of the state. Of course it is not usual for counsel to make commitments on behalf of the state-that is only for the agent-but nonetheless what you say is very carefully looked at. I do not think there is any doubt that it constitutes state practice. But it is state practice sub modo, because it is not free of the environment in which it occurs. The Court has to decide and the state has a compelling interest to present the best case, irrespective of what it really thinks. There may be a discrepancy between the actual view of the state on some particular issue and the view that you tell the state they will have to argue if they are going to have any chance of winning the case. That obviously has to be factored in. The stream does not rise above the source and the advocate does not rise above the court, so I think it is state practice sub modo. The second question in relation to Germans: yes. I have seen fewer Germans in action than francophones-with whom I count the Italians and the Belgians. Germans are somewhere in between the two, or at least the ones I have heard. They are really quite good and in the case of Simma and Frowein very good indeed. They tend to be less flowery, shorter, less literary and very much to the point [laughter]. And as for where we disagree, well, Alain will tell you that we do.

AP: I would say that I hope we do, at least under the rules of the game. On the two points on the contention and state practice, I entirely agree, unfortunately, with James [laughter]. Let me just add one thing on state practice. I think it is very interesting to use the pleadings before the ICJ or elsewhere to establish opinio iuris. Opinio iuris is something terrible to be proven, but I think it is good evidence of opinio iuris; so it is not only practice but maybe even more opinio iuris.

On the Germans: my view is that it is easier for me to be on the same

\footnotetext{
${ }^{13}$ See above $\mathrm{n} 1$.
} 
ground with my German colleagues than with my British colleagues. Their way of thinking is really proximate to ours. The problems with the Germans is that they are very interested in knowing whether they should put dots between I C J or not and this for me is rather exasperating [laughter]. Sometimes I put one and sometimes I put three dots without thinking, and this will keep you busy for long discussions with the Germans [laughter]. Beside this we have no real problems.

CR: We will now move on to our second debating point on which I think we may find perhaps a greater degree of divergence between the different common law and civil law approaches to authorities and evidence.

JC: There is a big difference between authority and evidence. Authority is the body of case law and other material on which you base what you say when making arguments. Evidence is the set of materials for the case, the documents and in some cases oral testimony. In terms of reference to authority, I think there is not a great deal of difference. I have a practice of almost never referring to academic writings but referring only to decisions of the Court or to good decisions of tribunals because-and it is part of the reason the Court does not refer to academic arguments either-if you refer to one you have to refer to them all-and good heavens, there are so many of them! There are a few canonical works which are exempt from that, Shabtai Rosenne's book on the International Court being perhaps the most notable among them. ${ }^{14}$ I think there is a slight difference of presentation in that the francophone advocates tend to footnote their texts in a certain way-certainly Alain does-which is quite a good idea because it means that the other side has to go and check if the references are right or not, which takes up valuable time; so my practice is to assume Alain is right and go around his argument by another route [laughter]. I do not think there is a great deal of difference in terms of reference to authority and that is part of the point. Despite differences in style and education, we are dealing with the same subject matter. I reject the idea that there is a French international law or an English international law: there is just international law. It is a bit like the elephant in the room of course, because for linguistic reasons no one ever grasps the whole beast-it is absolutely impossible-and you do perceive it to some extent through the prism of your own language. But I like to believe and I do believe that you still perceive the same object and not a different object. When it comes to evidence, however, there are major differences. Good francophone advocates are as good as anyone in mastering the dossier, which is the written bundle of evidence. But some have said of the Court that it has the worst of

${ }^{14}$ S Rosenne, The Law and Practice of the International Court, 1920-2005, 4 vols (2006). 
both worlds: it has lots of written evidence and lots of oral material as well. The francophone style in normal courts is to have a case properly pleaded in writing and then to have very brief oral advocacy-which in my experience on the OECD Administrative Tribunal is usually pretty ineffective, so you are left with the dossier. The English style used to be almost entirely oral advocacy with very little in writing, but that has changed with skeleton arguments. Skeleton arguments are approximating to pleadings, even in domestic cases and certainly in international cases. I think there is an important cultural difference in that francophone judges and francophone advocates tend to disdain oral examination of witnesses, whereas Anglophone and US counsel tend to think more highly of it. The Court is having to decide how to handle oral testimony in some of the pending cases involving scientific questions, the Whaling case for example. ${ }^{15}$ It brought it on itself, because in the Pulp Mills case it said-and quite rightly-that parties have to stop presenting evidence as advocacy through scientific advocates, which had been the previous practice. ${ }^{16}$ So we are about to see how that works out in the Ecuador $v$ Colombia case, ${ }^{17}$ if it does not settle, or the Whaling case, which will not settle, and see how the Court manages. Even so, I would say there is not as much difference as you would think. A very senior French advocate had to do the first cross-examination of his life in the Corfu Channel case-the first case the Court had-where there was expert evidence about the placement of mines in the Corfu Channel. ${ }^{18}$ The question was whether it was possible for the border guards on the coastline not to have known that the mines had been laid; quite a precise question, well handled by the Court. In the course of the case the French advocate had to conduct his first cross-examination ever, cross-examining a Yugoslav Naval Officer, and he extracted very valuable concessions from the Yugoslav Naval Officer, inter alia that Yugoslavia had laid the mines. He swore for-ever-after that cross-examination was the best method for getting at the truth [laughter].

AP: Well, the chair was right in saying that there are differences and we agree on what they are, so I will be very brief. With the authorities, there is no such

\footnotetext{
${ }^{15}$ See Whaling in the Antarctic (Australia $v$ Japan; New Zealand intervening), ICJ Verbatim Record, CR 2013/9, 27 June 2013 (morning), 38-71; CR 2013/10, 27 June 2013 (afternoon) 14-33; CR 2013/14, 3 July 2013 (afternoon), 14-59.

${ }^{16}$ Pulp Mills on the River Uruguay (Argentina v Uruguay), ICJ Reports 2010, p 14, 72.

${ }^{17}$ Aerial Herbicide Spraying (Ecuador v Colombia), Application Instituting Proceedings, 31 March 2008, <http://www.icj-cij.org/docket/files/138/14474.pdf> [accessed 15 August 2013].

${ }^{18}$ Corfu Channel (United Kingdom v Albania), ICJ, Minutes of the Sittings held from November 9th, 1948, to April 9th, 1949, Part I, p 537-643.
} 
thing as stare decisis in international law. With regret my British colleagues accept that and I think that they accept that jurisprudence constante is much more efficient than to stick to the strict doctrine of precedent. There is no difference between us because it is like that and clearly you cannot change the law, even the British accept that. That said, I think that they have some problem to accept or are not prepared to admit something else in the international law of evidence: it is the formidable un-formalism of the rules of evidence. For me there is only one rule of evidence before the ICJ: the rule is that there is no rule. My British and American colleagues have great difficulty to accept that. It causes them disarray and perplexity, probably because in the common law system the rules of evidence are extremely developed, much more than in the continental laws. We sometimes have long discussions in legal teams on the burden of proof-which is not a problem: you have to prove your case. There is no such thing as the burden of proof I think, but my American colleagues love to discuss at lengths the burden of proof, which I think is wrong. Of course you must have some limits-you can only present honest evidence-but that is all.

The second point - and it might be seen as having some links with honesty-is the dealings with witnesses and experts. The British, and even more the American advocates, are fond of having expert witnesses. I think its rubbish; as a Frenchman I would not trust a word of whatever a witness says. Even more so, for me prepared statements are totally insane. My view is that it has not worked, at least before the ICJ. The British and Americans are supposed to be very good in cross-examination, but what I have seen was desperate and of no use [laughter]. We should not introduce experts and I think the judges are not much more impressed than I am.

A last word on evidence-on something that for me is a real concern. This concern is the shocking tendency in modern international advocacy to use very exaggerated lengthy written pleadings. I have less in mind the pleading pieces themselves-although some are too lengthy-than the manner to put everything as an annex. This is true not only for the ICJ but may be even worse before arbitral tribunals. I think that the responsibility for this regrettable situation lies mainly with two culprits. First, modern technology: photocopying and the internet make it much easier than in the past to accumulate so-called evidence without any discernment, au hasard, just in case. I think it is regrettable and counter-productive. Now, I think technology in itself is neutral. It is what you make of it that is not neutral and somebody has to take responsibility for this really worrying drift. Here I am rather serious-I really mind this-and I am sorry to say that this responsibility is incumbent upon law firms like our 
sponsor. American and British law firms indulge in massively using these modern amenities, probably to impress their clients, but it is not helpful at all for the judges and the arbitrators. I am really exasperated by that and I call for reason in this respect. Too much is too much and we are well over too much. Once again, I think this drift is the responsibility of the big Anglo-American law firms.

JC: I have not yet heard an effective cross-examination in the Court, but I recently heard one in the Kishenganga arbitration between Pakistan and India. ${ }^{19}$ It was a cross-examination of one of their experts by Samuel Wordsworth, now a QC, who had the Court transfixed; it devastated the witness-it completely disproved what he was saying. So it can be effective in the hands of a master, but it requires very careful preparation. Because of the limited amount of time in the Court it is unlikely that the circumstances will allow for cross-examination in ICJ proceedings. But in arbitrations you will sometimes see very effective cross-examinations. I think the Court is a bit betwixt and between at present on the question of evidence.

I agree entirely with what Alain said about excessively long pleadings. A particular abuse committed by myself-I fully admit-is submitting a rejoinder that is longer than the counter-memorial. The Court has really got to do something about that: either by enforcing the rule that the rejoinder can only respond to questions of difference, or by introducing a rule that there will in general be only one round of written pleadings, with a further exchange of information prior to the case-I think there is a need for the Court to be brought up to date with any continuing situation, especially in environmental cases. But that does not require a second round of written pleading. In a couple of cases recently, one side produced a memorial and the other side produced a counter-memorial, and then the claimant told the Court it was happy to go to trial on the basis of those pleadings. In one case the other side was extremely upset because they had reserved a number of issues for the rejoinder. In the other case they were forewarned and they accepted it. Long second round pleadings are an unsatisfactory practice and I think the Court should start to indicate maximum length, because if you have a good case you can make your case in three hundred pages-you do not need six or seven hundred. I think it would help in terms of economy of pleading. I agree entirely also with annexes. The tendency is to pile material on. The whole basis of documentary references before the court is going to have to change anyway because the internet has transformed things.

\footnotetext{
${ }^{19}$ See Indus Waters Kishenganga Arbitration (Pakistan v India), PCA, <http://www.pca-cpa.org/show page.asp?pag_id=1392> [accessed 15 August 2013].
} 
Material on the internet is publicly available within the meaning of the Court's rules; therefore everything is publicly available-including the works of Corneille I understand [laughter].

CR: The floor is now open for questions.

Henri Decoeur: I am curious to know your opinion about a new generation of litigators who might have been trained in both traditions and whether this will lead to a new style of advocacy, where they may be picking the best of both traditions or perhaps the worst.

Daniel Behn: I wonder if either of you could say, in your experience, what is the most bizarre evidentiary information that has ever been presented in a case that you have been involved in?

Mutaz Qafisheh: As a non-anglophone or francophone, I feel that when French jurists speak in English, the English is clear for me; and when the English speak in French, their French is clear for me. From my studies of international law at Geneva, I have noticed a difference between common law or Anglo-Saxon law, and continental law. When I read pieces of the ICJ, for example, or various books written in French or in English, I could not really notice a difference. My impression is that international law and the Court are heading towards a more truly international route, especially when we look at, for example, dissenting opinions of young English or young French judges of the ICJ. From your experience and impressions, where is the Court heading? Are we going towards a more anglophone, a more Anglo-American or more Anglo-Saxon system, or towards a more continental system, or are we forming a new international law approach that will be truly international?

Rumiana Yotova: Both of you referred to the use of modern technology in international disputes, so I was wondering if you could elaborate a bit more on that with reference to oral pleadings, because there seem to be different trends in investment arbitration as opposed to the ICJ. Can you identify best practices and good strategies for the use of modern technology?

[Conference participant] I have two questions and I would be very interested in your impressions. The first is about diversity in the advocates before the International Court. One thing that we have gleaned from your discussion is that it is very difficult to generalise about Anglo-American and continental advocacy before the Court because the cast list is very small. There is a divergence of views, I think, both among states and among those who practice in international law as to whether the Court is really interested in seeing new and different people. It seems to some that there is a certain novelty in having somebody new stand up before the Court but I am not sure whether 
actually, genuinely, the Court is interested in hearing from new people or if they prefer to hear from those they know and trust. My second question is about procedural reforms in the Court, whether you could comment on your views on the prospects for procedural reform. I am not just talking about the length of pleadings, but also about the time-frames before the Court-in a matter in which you were both recently involved, the written pleadings closed, I think, seventeen months before the Court held a two-week hearing. It seems to me that this is an area that is ripe for reform and I would be interested in your views.

JC: Henri, thank you for your question about the possibility of people with training in both traditions. I think it is happening, to some degree. Alain has appeared in more than 40 cases. One of the reasons for that is his quality; another is that a number of them have been francophone-only cases. It is said the English party always feels they need a francophone on board but the French party does not always feel that they need an anglophone on board. Are the differences converging? They are to some extent, but this depends on the question I already identified as 'what happens in the next generation?' One thing that the large Anglo-American firms are doing-certainly in arbitration and even before the Court-is proliferating interlocutory proceedings, which is causing no end of trouble, and quite a lot of indiscipline. That is Anglo-American and not francophone, very definitely, and something that needs to be brought under control.

Acknowledging the internet in oral proceedings: well, the old disciplines about publicly available material have broken down, and have not been replaced by any new disciplines. The Court's sense in recent practice directions has been to say that everything has to be on the table in advance, which is fine, but if you cannot police that absolutely, I think there is something of a problem.

As to the question of whether the Court welcomes new voices, I think it does very much. One of Alain's associates, Alina Miron, presented the map speech for Thailand in the recent Temple case. ${ }^{20}$ It is the best map speech I have heard, and it made her an instant overnight celebrity in Thailand, where it was broadcast. I think they very much welcome that-and I remember Kate Parlett making her debut at the Court as well for Costa Rica. ${ }^{21}$ But there is a tendency, if you have been practising for a while and if you obey the basic rules-and the most

\footnotetext{
${ }^{20}$ Request for Interpretation of the Judgment of 15 June 1962 in the Case concerning the Temple of Preah Vihear (Cambodia $v$ Thailand) (Cambodia $v$ Thailand), ICJ Verbatim Record, CR 2013/3, 17 April 2013 (morning), 34-50.

${ }^{21}$ Dispute regarding Navigational and Related Rights (Costa Rica v Nicaragua), ICJ Verbatim Record, CR 2009/3, 3 March 2009 (morning), 43-52.
} 
important basic rule is 'do not make any statement that you know not to be true'; you can make arguments that you know to be bad arguments, and sometimes you have to. I think the Court does come to trust certain advocates, because it recognises that they are making the best argument available-which may not be a very good argument, but they are not telling lies. That is something that you must never do with the Court, irrespective of professional traditions or whatever. On questions of fact, if you know something to be the case, you can be silent about it, but you cannot say the contrary, otherwise you discredit yourself very quickly.

On procedural reform, I think the Court is in for a period of procedural reform-I very much hope so. In particular, I think the Court needs to develop an accelerated procedure, whereby when states parties are prepared to accept it, the Court will undertake to deal with the case within one or at most two years from beginning to end; indeed it took the International Tribunal for the Law of the Sea one year to deal with the Bangladesh/Myanmar case. ${ }^{22}$ There is no reason why a case should take six or seven years. In order to do so the parties will have to agree to have one round of written pleadings only and not to have bifurcation of jurisdictional or admissibility objections. There are some prerequisites, but I hope the Court can develop procedures that will meet some of these concerns. Presently there are more inter-state arbitrations than there are real cases before the Court, and that is a matter of some concern.

AP: In respect to legal 'bi-cultures', well, we can have the best or the worst of two worlds, but I think that concerns first the new generation. I think your generation is much more 'international' than we were; I was never trained in any other country than mine, while most of you have changed continent, changed language. Again, I think international law is not just Latin or common law; it is both. This said, all of you, including James, always speak of francophone lawyers, and I think it is not a problem of francophonia; honestly, it is not because the French look to be dominant among the continental lawyers that it is a problem of language. I think language does not really matter; we have not spoken of that-and yes, my experience in the ILC is that we should keep both languages. I am a bit of a traitor: I think there is only one international language and this is not French. Personally I think that English is okay; it is a good way of communication. Usually you are very generous in accepting my strange English. However, I think that it is very useful to have what I would call a 'checking language'. For example, in the ILC drafting committees, it was very interesting to see that sometimes you cannot translate a draft in French into English or from English into French, and

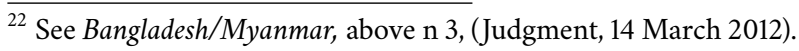


this is a bad sign-if you want to make good international law, you must be able to so. For this reason I am still advocating two languages-it happens to be French in the ICJ, but I think it does not really matter: what you need is to have another language corresponding to another culture.

Well, you asked what was the most bizarre experience. In that respect, probably the most incredible one was the Republic of Congo $v$ France, where a French advocate appeared who is seen as one of the best-he is a very bad lawyer and a bad man as well. I was advocate for France and he was the advocate for Congo. He made an incredible show and some minutes before the end of the allocated time he still had not said a single word on the real case. President Shi, who is Chinese and a very reserved man, interrupted him and said 'I would like to speak a few words; may I interrupt you for a moment? It has been agreed by the Parties that for the second round, each Party will have a maximum time of one hour; now it is already 10.35 a.m. ${ }^{\text {,23 }}$ Maître Vergès (that is his name) did not, however, tackle the topic-he was incapable of doing so [laughter].

You have asked many questions that call for a lengthy answer. I draw your attention to a good article by Cesare Romano on the americanisation of international litigation. ${ }^{24}$ It is well perceived and it is quite right that the Latin countries should be aware that the field is changing. Yet even if all judges speak English, or are used to English or common law reasoning, their background remains what it is. I am a nullity in French law; I know nothing about French law, I have forgotten everything-I took my degrees 45 years ago and I have no idea of French law. I am not an advocate in the French bar and inside my international legal teams, quite often I am asked, 'what does French law say on this or that?' Very shamefully, my answer nearly ritually is-and has to be-'I have no idea; I do not know.' But I am French, and my legal background is French, even though I do not practice French law.

Well, the lengths of cases-I think it deserves another discussion. My view is that the Court cannot be reformed, really, and it does not matter: it has no more cases.

CR: We will move to our final debating point, which is merging relations with the client and duty to the Court. Alain, I think you were going to lead on this. We will try and keep the comments brief to allow a final few minutes for questions.

AP: Thank you. Well, these are both interesting questions. I think they are

\footnotetext{
${ }^{23}$ Certain Criminal Proceedings in France (Republic of the Congo v France), ICJ Verbatim Record, CR 2003/22, 29 April 2003 (morning), p 20.

${ }^{24}$ C Romano, 'The Americanization of International Litigation' (2003) 19 Ohio St J Disp Res 89.
} 
bound, so it does not really matter to merge them.

Relations with the client: if there are differences, it is much more a problem of personality of counsel than a real difference in culture. If I can summarise what I would have developed if we had more time, I would say, brutally, that usually I see my British or American counterparts as being more keen to please the client than we are, and certainly than I am. Just to give you an example, in a case, not very long ago-and I can tell you which one although the adversary is sitting in front of me-in Indonesia/Malaysia, we lost, rightly, by fifteen votes against one. ${ }^{25}$ The one who voted for us-I was for Indonesia, James was 'Malaysian'-was the Judge ad hoc appointed by Indonesia. In that case, my British and American colleagues kept on explaining to the client, 'oh, we have fifty percent at least'. It was wrong-it was a lost case, we knew that, and I was really shocked. You could say, 'well, it was specific to these counsel'; honestly, I am not sure. I have seen quite regularly that my Anglo-Saxon counterparts are rather more accommodating to the client. In the same way, they also have more than we have-and certainly than I have-an inclination for procedural incidents. I think that making procedural fuss is not good strategy. But I have no doubt that my American and British colleagues, particularly the Americans, are more inclined to create these kind of incidents, and I must admit that, usually, it pleases the clients. The client loves to show its muscle on this ground. I disapprove.

I will end this part on the relations with the client by reading something that was written by James, so he will not have his word on this topic, because I do it for him [laughter]. I quote: 'evidently it is the function of the advocate to comply with the instructions of the government or other party and to present the case in as forceful and vigorous a way as possible. At the same time it is not the function of the advocate simply to say things for money, nor unquestioningly to present the client's case in the way the client would have it without regard to any of the actual difficulties. Rather, it is the function of the advocate to seek to persuade the tribunal in such a way as to preserve the essentials of the client's case. This is a delicate matter requiring trust between the client, through the agent, and the advocate. In search for a proper outcome the advocate is not merely a mouthpiece, but rather an active intermediary. ${ }^{26}$ I could not have said it better. Clearly, James and I have no difference on this. I nevertheless have a perception that Anglo-Americans are a bit too accommodating to their clients

${ }^{25}$ See Sovereignty over Pulau Ligitan and Pulau Sipadan (Indonesia/Malaysia), ICJ Reports 2002, p 625.

${ }^{26} \mathrm{~J}$ Crawford, 'Advocacy Before International Tribunals In State-To-State Cases', in R D Bishop \& E G Kehoe (eds) Art of Advocacy in International Arbitration (2 ${ }^{\text {nd }}$ edn, 2010) 38. 
and they should not be.

As for the duty to the court, I think the question is very different whether you speak of the ICJ or of an arbitral tribunal, in particularly in investment cases. For the Court, I think it works well, I have never seen any excesses. Therefore, I would rather mind to have a very detailed deontological code; it is superfluous. For ICSID tribunals I have the other view: I think we must try to have some deontological guidance and, if possible, very tough ones. My second remark-and it will be the last one-is that I have always heard my Anglo-American colleagues saying, 'we must help the Court, we must be helpful to the judges.' Come on, we must be helpful to the client! We must be honest to the Court-I have never lied before the Court and I hope I will never do. We must be clear in not letting the client produce some fraudulent documents. I have been told that in one case-in which I was not appearing-something like that happened. But 'never lie' is the only limit; besides this, the issue is to make the best case for the client. The outcome will be a solution adopted after the adversarial process and the judges can deliberate between themselves. So, I rather smile at my colleagues who claim that we must be helpful to the Court. Once again, I think we must be helpful to the client, and being helpful to the client is to be helpful to the Court.

JC: You may wonder why states fight cases that they are bound to lose. I had the same experience with the Libya/Chad case, in which Alain was on the other side; we knew in advance that we would lose that case. ${ }^{27}$ The point of settlement of that case was the reference to the Court, it was not the decision of the Court. In fact, with a lot of work the firm that is now Eversheds (it had a different name then) put together a quite decent argument, which you will see in the dissenting opinion, ${ }^{28}$ and it stood up for about 15 minutes, and it then laid down and died. The client was left in no doubt about that. We have recently seen an example of a case, where again I was against Alain, where I told the client-I will not mention the name of the party-again and again, 'you will not get the line you want. You may get something that is acceptable, but you will not get the line you want.' They did not listen. I went to the capital concerned and gave a series of seminars to professors and others who had never read the Court's jurisdictional judgment, did not understand the case, and had the fixed idea that this line they would never get was the line they were going to get. If the client does not want to listen there is not much you can do; you argue the case as well as you can, including arguing in the alternative, in the second round, which is what we did. There comes a

\footnotetext{
${ }^{27}$ See Territorial Dispute (Libyan Arab Jamahiriya/Chad), ICJ Reports 1994, p 6.

${ }^{28}$ Ibid, Dissenting Opinion Judge Sette-Camara, p 93.
} 
point where you simply have to do your best and then comply with instructions. And instructions may turn out to be right or wrong; in another case I protested against bringing in what seemed to be extraneous matters. I was told 'no, we must put them in'. It turned out that the client was right and I was wrong, because the extraneous matters were no longer extraneous to the case.

Duty to the court: I have nothing to add to what Alain said. The forgery case, Qatar v Bahrain case, backfired very seriously. ${ }^{29}$ I think one of the counsel, not the senior counsel, was partly responsible. So you should never use forged documents - that almost goes without saying. You do have a duty of honesty; beyond that your duty is to the client.

It is important, in presenting a case, to leave the Court with an alternative. I think in retrospect that was a mistake I made in the Gabčkovo-Nagymaros case. ${ }^{30}$ We knew we were going to lose aspects of that case and we could have lost it all; it could have been a $100 \%$ win for Slovakia, which it was not. Hungary could not have won it without giving the Court an alternative to the status quo, and I think we did not do that. I think the strategy of pleadings is very important, to give the court somewhere to go if you are to get the result that is tolerable to the client. You need to be honest with the client about the chances-I agree entirely with what Alain said about Indonesia/Malaysia, where I was on the Malaysian side. We knew we were going to win that case, but we won it because of Eli Lauterpacht, who made the argument that succeeded; I made the argument that failed.

CR: That leaves us about three minutes for a final question or two.

Simon 0'Connor: I would just like your thoughts on the very interesting question that came up in an early panel, about the client of government lawyers. I would be interested in your thoughts who the clients of international lawyers are. I think there is a difference between international advocates and international lawyers, and there is also a question about your clients and the interests you represent.

Geraldo Vidigal: I would like to know how clients react to and whether they are satisfied, to some extent, with dissenting opinions that favour their case when they lose, and whether it matters if it is delivered by the ad hoc judge, and if it is a stronger dissenting opinion or not.

JC: The question who the client is is very interesting and becomes a problem in certain cases. Not so much at the International Court, because in the

\footnotetext{
${ }^{29}$ See Maritime Delimitation and Territorial Questions between Qatar and Bahrain (Qatar v Bahrain), ICJ Reports 2001, p 40.

${ }^{30}$ See Gabčkovo-Nagymaros Project (Hungary/Slovakia), ICJ Reports 1997, p 7.
} 
International Court there will have been a decision of one party-and probably both-to take the case to that level. That tends to aggregate the bureaucracy behind you. It may also shift the locus of power in the bureaucracy from the internal ministry associated with the actual dispute to the ministry of foreign affairs, which can be quite helpful in dispute settlement. The problem is where you have a third interest in the case, which is not the interest of either of the governments. That was true, for example, in the Volga Prompt Release case between Australia and Russia, because there it was the interest of the ship owner, who was neither Australian nor Russian, and was paying for the case-in fact the Russians did not really want the case and that did not help. ${ }^{31}$ I think maritime cases are notorious for bringing in third parties. More recently, in Argentina $v$ Ghana case, there was an interest of a third party, the judgment creditor. ${ }^{32}$ It was not represented before the Court, but it was present in the Court. In interstate arbitration, we do not really have mechanisms for presentation of third views. That can be a real problem.

In response to the question about dissents, I have never known a government that lost and that was happy about the dissent [laughter]. There is a case on annulment at ICSID at present, Deutsche Bank $v$ Sri Lanka. ${ }^{33}$ There is a very strong dissenting opinion. That is enormously helpful in terms of annulment because you read the dissent-I speak for counsel of the losing party-and you think 'how on earth did the majority get where they got?' Even in the International Court, where there is no appeal, it is some solace. For example, a number of judges would have got rid of the 1977 Treaty in the Gabčkovo-Nagymaros case. I got some solace from that, though I do not think Hungary got any.

AP: Well, on the first question, it is true that you have the impression when you look at the case law of the International Court that it is only about sovereign interests. It is interesting that this is not always the case and that behind the scenes you sometimes have very powerful interests. In two recent cases-I will not tell you which ones-I was surprised to see that I was not paid by the states; I was paid by private entities. It is well known that Barcelona Traction was not a case between Belgium and Spain, but between the shareholders of the Barcelona and

\footnotetext{
${ }^{31}$ The 'Volga' Case (Russian Federation v Australia) Prompt Release, ITLOS (Judgment, 23 December 2002).

32 The 'ARA Libertad' Case (Argentina v Ghana), ITLOS (Order on Provisional Measures, 15 December 2002).

${ }^{33}$ See Deutsche Bank AG v Democratic Socialist Republic of Sri Lanka, ICSID Case No ARB/09/2 (Award, 31 October 2012).
} 
Spain. ${ }^{34}$ I agree with James also on that.

On the dissenting opinions, certainly for French or more generally continental lawyers, it is strange. When I started as a student or a young professor, I was absolutely against it. I thought it threatened the authority of the Court. Now I have changed my mind. I think it is very useful, and it can shine a light on some very important points. However, there must be no exaggeration; one of the actual judges apparently has decided that he will append to any decision of the Court (whether a judgment or any kind of order) an opinion at least twice as long as the Court's decision itself. I think that is rather outrageous. But I believe dissents can be helpful. I think the same goes for judges ad hoc: you can criticise the principle, but I do not. I think it is more comfortable for states to have the possibility of having a judge ad hoc. For judges ad hoc it is terribly important to be able to express themselves and to decide whether they would dissent or deliver only an individual opinion. My recommendation to future judges ad hoc is that, even if his or her appointing side loses, it is better to append an individual opinion than a dissenting opinion. A dissenting opinion is a clear signal that your appointing party has lost.

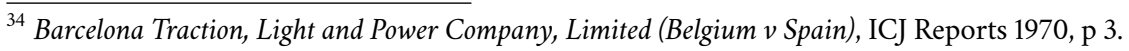

